\title{
Characteristics of Non-Alcoholic Fatty Liver Disease Patients at Dr. M. Djamil General Hospital Padang
}

\author{
Husna Yetti*, Nada Utami Prahastiwi ${ }^{* *}$, Restu Susanti**, Eva Decroli****, \\ Saptino Miro ${ }^{* * * *}$ \\ ${ }^{*}$ Department of Public Health, Faculty of Medicine, Universitas Andalas, Padang \\ ${ }^{* *}$ Faculty of Medicine, Universitas Andalas, Padang \\ ${ }^{* * \star D e p a r t m e n t ~ o f ~ N e u r o l o g y, ~ F a c u l t y ~ o f ~ M e d i c i n e, ~ U n i v e r s i t a s ~ A n d a l a s / D r . ~ M . ~ D j a m i l ~ G e n e r a l ~ H o s p i t a l, ~ P a d a n g ~}$ \\ ${ }^{* * * *}$ Department of Internal Medicine, \\ Faculty of Medicine, Universitas Andalas/Dr. M. Djamil General Hospital, Padang
}

\section{Corresponding author:}

Husna Yetti. Department of Public Health, Faculty of Medicine, Universitas Andalas. Jl. Perintis Kemerdekaan No.94 Jati Padang Indonesia. Phone: +62-751-31746; facsimile: +62-751-32838. Email: husnayetti@med. unand.ac.id

\section{ABSTRACT}

Background: Non-alcoholic fatty liver disease (NAFLD) is emerging as chronic liver disease, both in developed and developing countries. NAFLD affects up to $25 \%$ population worldwide. The incidence of NAFLD is associated with various risk factors supporting the development of the fatty liver. This study aim is to know the characteristics of NAFLD patients.

Method: Retrospective study was conducted from medical records to find the characteristics of patients diagnosed with NAFLD at Dr. M. Djamil General Hospital from January 2016-December 2018. Patient whose consumed drug that can cause fatty liver was excluded.

Results: Seventy-seven patients were diagnosed with NAFLD. The majority of NAFLD patients were male and female at 36-45 years old and female at $>65$ years old. Unemployed females were more prevalent compared to males. Dyslipidemia was the most component of a metabolic syndrome found in NAFLD patients. From laboratory findings, $55.56 \%$ of patients have increased aspartate aminotransferase (AST) levels, while $52.78 \%$ have increased alanine aminotransferase (ALT) levels. Ultrasonography was used widely as a diagnostic device to detect NAFLD. Pharmacological therapy based on American Association for the Study of Liver Disease (AASLD) recommendation that used widely to treat patients with NAFLD was statin.

Conclusion: The incidence of NAFLD was found to vary in different age ranges and sexes. Dyslipidemia occurred in most of NAFLD patients. AST and ALT levels increased in about half of the patients. Abdomen ultrasound as a diagnostic modality that was widely used.

Keywords: characteristics, non-alcoholic fatty liver disease (NAFLD), metabolic syndrome

\footnotetext{
ABSTRAK

Latar belakang: Non-alcoholic fatty liver disease (NAFLD) adalah salah satu penyebab penyakit hati kronik di negara majudanberkembang. Penyakit ini diperkirakan memengaruhi $25 \%$ populasi di seluruh dunia. NAFLD dapat terjadi akibat berbagai faktor risiko yang mendukung perkembangan penyakit ini. Tujuan penelitian ini adalah untuk mengetahui karakteristik pasien NAFLD.

Metode: Studi retrospektifmenggunakan rekam medis untuk mengetahui karakteristik pasien NAFLD antara Januari 2016-Desember 2018 di RSUP Dr. M. Djamil Padang. Pasien yang mengonsumsi obat yang dapat menyebabkan perlemakan hati dieksklusi.
} 
Hasil: Dari 77 pasien NAFLD, mayoritas pasien NAFLD adalah laki-laki dan perempuan berumur 36-45 tahun, serta perempuan berumur $>65$ tahun. ari jenis pekerjaan ditemukan sebgian besar adalah perempuan yang tidak bekerja. Komponen sindrom metabolik yang paling banyak dialami oleh pasien NAFLD adalah dislipidemia. Pada pemeriksaan tes fungsi hati diketahui 55.56\% pasien mengalami peningkatan kadar aspartat aminotransferase (AST) dan 52.78\% pasien mengalami peningkatan alanin aminotransferase (ALT). Pemeriksaan radiologi yang banyak digunakan untuk pasien NAFLD adalah ultrasonografi abdomen. Terapi farmakologis sesuai rekomendasi AASLD yang paling banyak dikonsumsi pasien adalah golongan statin.

Simpulan: Kejadian NAFLD ditemukan bervariasi dalam rentang umur dan jenis kelamin yang berbeda. Dislipidemia diderita oleh sebagian besar pasien NAFLD. Kadar AST dan ALT meningkat pada lebih dari setengah pasien. USG Abdomen merupakan modalitas diagnostik yang banyak digunakan.

Kata kunci: karakteristik, non-alcoholic fatty liver disease (NAFLD), sindrom metabolik

\section{INTRODUCTION}

Non-alcoholic fatty liver disease (NAFLD) is one of the causes of chronic liver disease in the $21^{\text {st }}$ century AD. ${ }^{1}$ NAFLD have a wide spectrum of fatty liver, as evidenced by radiological or histopathological examination in individuals without significant alcohol consumption (for female $>10$ grams per day and men $>20$ grams per day). There are no secondary causes for fatty liver. ${ }^{1,2}$ NAFLDis ranging from simple steatosis (NAFL), non-alcoholic steatohepatitis (NASH), and hepatic cirrhosis. ${ }^{1,3}$ The term of NAFLD was first introduced by Ludwig in 1980 through his research reported histological changes in the liver. ${ }^{4}$

Since the beginning of the $21^{\text {st }}$ century AD, there have been changes in human lifestyles in most regions of the world. This problem causing the prevalence of non-communicable diseases increased. ${ }^{5}$ The exact prevalence of NAFLD is still unknown. Most of the available data comes from epidemiological estimation. In recent years, NAFLD is the most common cause of chronic liver disease, affects up to $25 \%$ of the world's population. ${ }^{6}$ The highest incidence rates are the Middle East (32\%), South America (31\%), Asia (27\%), United States (25.8\%), and Europe (23\%). ${ }^{7}$

NAFLD is linked with metabolic syndrome. Metabolic syndrome is a cluster of health disorders that occur synchronously. It consists of central obesity, dysglycemia, dyslipidemia, and hypertension. Those conditions, known as risk factors of various diseases, included NAFLD. Metabolic syndrome can cause organ dysfunction through the lipotoxicity process due to excessive fat accumulation. ${ }^{8}$ This study was performed to know the characteristics of NAFLD patients in Dr. M. Djamil General Hospital Padang.

\section{METHOD}

The retrospective study was used through a medical record review of patients diagnosed with NAFLD at Dr. M.Djamil General Hospital between the period of January 2016 - December 2018. The sample of this study is part of the population that meets the inclusion criteria and does not meet the exclusion criteria. Subject inclusion criteria consist of patients diagnosed with NAFLD and written in the medical record data of Dr. M. Djamil General Hospital. Subject exclusion criteria are patient whose consumed drug that can cause fatty liver.

Data on patients' primary characteristics, body mass index (BMI), blood pressure, laboratory, diagnostic modality, and drug consumed by the NAFLD patients were obtained from hospital medical records. Descriptive analysis was performed according to the collected data.

\section{RESULTS}

During the study period, 77 patients have met the inclusion criteria. The characteristics of NAFLD patients based on age, gender, and occupation were varied. Incidence of NAFLD in male patients at 36-45 years old are frequent, while the incidence at 56-65 years old male and female patients were similar. The majority of the patients were unemployed females.

Table 2. shows that $76.47 \%$ of NAFLD patients have abnormal BMI scores. Based on available data above, $67.65 \%$ of patients have BMI above the normal score, and $8.82 \%$ of patients with underweight BMI.

The categorization of each blood examination result is based on values compiled by the Indonesian Ministry of Health. Out of 62 patients who examined lipid profiles, $70.97 \%$ of patients had a low HDL level, $75.81 \%$ of patients had LDL level above optimal, and 
Table 1. The characteristics of non-alcoholic fatty liver disease (NAFLD) patients based on age, gender, and occupation

\begin{tabular}{lll}
\hline & Variable & \multicolumn{1}{c}{$\mathbf{n ~ ( \% )}$} \\
\cline { 2 - 3 } Age (years old) & \multicolumn{1}{c}{ Female } & Male \\
$0-5$ & $1(1.30)$ & $1(1.30)$ \\
$5-11$ & $1(1.30)$ & $0(0)$ \\
$12-16$ & $0(0)$ & $0(0)$ \\
$17-25$ & $3(3.90)$ & $1(1.30)$ \\
$26-35$ & $2(2.60)$ & $4(5.19)$ \\
$36-45$ & $10(12.99)$ & $11(14.29)$ \\
$46-55$ & $7(9.09)$ & $5(6.49)$ \\
$56-65$ & $10(12.99)$ & $10(12.99)$ \\
$>65$ & $7(9.09)$ & $4(5.19)$ \\
Occupation & & $12(17.39)$ \\
Employee & & $2(2.90)$ \\
Professional staff & $6(8.69)$ & $5(7.25)$ \\
Service workers and sales workers in store and markets & $1(1.45)$ & $1(1.45)$ \\
Agriculture and animal husbandry workers & $0(0)$ & $1(1.45)$ \\
Though workers, cleaning workers and related & $0(0)$ & $7(10.14)$ \\
Soldier and police & $0(0)$ & $3(43.48)$ \\
Unemployed & &
\end{tabular}

Table 2. BMI, laboratory findings and blood pressure of NAFLD patients in Dr. M. Djamil General Hospital

\begin{tabular}{ll}
\hline \multicolumn{1}{c}{ Variable } & \multicolumn{1}{c}{$\mathbf{n}(\%)$} \\
\hline Body mass index (BMI) & $0(0)$ \\
Moderate underweight & $3(8.82)$ \\
Underweight & $8(23.53)$ \\
Normal & $8(23.53)$ \\
Overweight & $6(17.64)$ \\
Obese & $9(26.47)$ \\
Moderate obese & \\
High-density lipoprotein (HDL) & $44(70.97)$ \\
Low & $18(29.03)$ \\
Normal & \\
Triglyceride & $41(66.13)$ \\
Normal & $10(16.13)$ \\
Borderline & $10(16.13)$ \\
High & $1(1,61)$ \\
Very high & \\
Low-density lipoprotein (LDL) & $15(24.19)$ \\
Optimal & $22(35.48)$ \\
Almost optimal & $6(9.68)$ \\
Borderline & $8(12.90)$ \\
High & $11(17.74)$ \\
Very high & \\
Blood glucose & \\
Fasting glucose & $3(4.84)$ \\
Hypoglycemia & $38(61.29)$ \\
Normal & $20(32.26)$ \\
Hyperglycemia & \\
Nood glucose level & $5(8.06)$ \\
Hyperglycemia & $1(1.61)$ \\
Hypotension & $0(0)$ \\
Normal & $42(56)$ \\
Hypertension & $33(44)$ \\
\hline &
\end{tabular}

$33.87 \%$ had triglyceride levels above normal. Out of 67 patients with NAFLD who did a blood sugar examination, $31.34 \%$ of patients suffer hyperglycemia. While the results of blood pressure from 75 patients show, $44 \%$ of them suffer hypertension.

Table 3. Component of a metabolic syndrome found in NAFLD patients in Dr. M. Djamil General Hospital Padang 2016-2018

\begin{tabular}{lc}
\hline Components of metabolic syndrome* $^{*}$ & $\mathbf{n}$ \\
\hline Dyslipidemia & 59 \\
Hypertension & 33 \\
Obesity & 23 \\
Diabetes Mellitus & 21 \\
\hline *A patient could have more than one component of metabolic syndrome
\end{tabular}

${ }^{*}$ A patient could have more than one component of metabolic syndrome

Based on Table 3. a component of metabolic syndrome, which was commonly experienced by NAFLD patients, was dyslipidemia. The patient could have one, two, three, or all components of metabolic syndrome. More than half of the patients had two components of metabolic syndrome, while only a few patients had all components of metabolic syndrome in the study period.

Based on Table 4. 55.56\% of patients had an elevated level of AST, and $52.78 \%$ of patients had an increased level of ALT.

Table 4. Results of liver function tests of NAFLD patients at Dr. M. Djamil General Hospital Padang in 2016-2018

\begin{tabular}{lcc}
\hline \multirow{2}{*}{ Variable } & \multicolumn{2}{c}{$\mathbf{n ~ ( \% )}$} \\
\cline { 2 - 3 } & \multicolumn{1}{c}{ Male } & Female \\
\hline Aspartate aminotransferase (AST) & & \\
$\quad$ Normal & $14(19.44)$ & $18(25)$ \\
High & $19(26.39)$ & $21(29.17)$ \\
Alanine aminotransferase (ALT) & & \\
$\quad$ Normal & $15(20.83)$ & $19(26.39)$ \\
$\quad$ High & $19(26.39)$ & $19(26.39)$ \\
\hline
\end{tabular}


The most commonly used diagnostic modality in establishing a diagnosis of NAFLD is ultrasonography (abdomen ultrasound). In some cases, patients get examinations using more than one diagnostic modality.

Table 5. Diagnostic modalities used in NAFLD patients at Dr. M. Djamil General Hospital Padang from 2016-2018

\begin{tabular}{ll}
\hline Device & $\mathbf{n}(\%)$ \\
\hline Ultrasonography & $68(88.31)$ \\
Fibroscan & $7(9.09)$ \\
computed tomography (CT) scan & $3(3.90)$ \\
Magnetic resonance imaging (MRI) & $0(0)$ \\
Liver Biopsy & $3(3.90)$ \\
\hline
\end{tabular}

According to Table 6, pharmacological therapies based on American Asociation for the Study of Liver Disease (AASLD) recommendation commonly consumed by NAFLD patients at Dr. M. Djamil General Hospital Padang in 2016-2018 is statin. Besides, other drugs are also consumed by NAFLD patients, as prescribed by the doctor for other considerations.

Table 6. Drugs consumed by NAFLD patients in Dr. M. Djamil General Hospital Padang from 2016-2018

\begin{tabular}{ll}
\hline Drugs list & $\mathbf{n}(\%)$ \\
\hline AASLD recommendation & \\
Metformin & $6(7.89)$ \\
Glitazones & $0(0)$ \\
Omega -3 & $0(0)$ \\
Ursodeoxyicholate acid & $6(7.89)$ \\
Statin & $23(30.26)$ \\
Vitamin E & $6(7.89)$ \\
\hline
\end{tabular}

\section{DISCUSSION}

The study found that the majority of NAFLD patients at Dr. M. Djamil General Hospital Padang in 2016-2018 were 36-45 years old. These results matched with data from epidemiological research conducted by Liu et al (2018), which states that most NAFLD patients are diagnosed at the age of the $4^{\text {th }}$ $5^{\text {th }}$ decade of life. However, NAFLD can also occur in various age categories, ranging from children to the elderly. ${ }^{2}$ Based on a cross-sectional study by the National Health and Nutrition Examination Survey (NHNES) III, the prevalence of NAFLD by age group showed the lowest prevalence occurs at age $<30$ years. While the highest prevalence occurs in the age group 40-49 years. ${ }^{9}$

With increasing age, changes in the structure, and function of the liver can affect hepatic metabolism and detoxification processes. Anatomic and physiological changes in the liver due to the aging process can be in the form of a loss of regenerative ability and a decrease in the free radicals collection system in the liver, thus, increasing oxidative stress. ${ }^{10}$
NAFLD patients were dominated by females, with a ratio of 1.14: 1 to male. Bertolotti et al (2014) conducted a cohort study involving three continents: Asia, Europe, and America. The result shows the most frequent occurrence of NAFLD in men aged $<50$ years. Whereas in women the incidence of NAFLD increases during menopause. ${ }^{10}$

Based on occupation, most of the NAFLD patients are unemployed. According to the Indonesian Standard of Job Classification (KBJI 2002), the definition of occupation is a series of tasks designed to be carried out by one person and, in return, was given wages and salaries according to the classification and the severity of the work. ${ }^{11}$ The group of unemployed patients in this study consisted of children, students, jobless individuals, homemakers, and retirees. Out of the 37 unemployed patients, 30 patients were female patients, and seven male patients. According to the study of Stepanova et al (2017), the unemployment rate in patients suffering from chronic liver disease (including NAFLD) is higher compared to individuals who do not experience chronic liver disease. This is due to the disability caused by the disease so that individuals who have chronic liver disease cannot work. ${ }^{12}$

The prevalence of NAFLD is directly proportional to metabolic syndrome. The component of metabolic syndrome, which is most experienced by NAFLD patients in Dr. M. Djamil Padang General Hospital, is dyslipidemia. An individual can experience dyslipidemia if there is an abnormality in one or more of the lipid profile components. ${ }^{13}$ Based on examination of lipid profile levels, as many as $70.97 \%$ of patients who do lipid profile examination had low HDL levels, $75.81 \%$ of patients had above optimal LDL level, and $33.87 \%$ had triglyceride levels above normal.

Intrahepatic fat accumulation comes from an abnormality of fat metabolism, e.g., increased lipolysis, free fatty acid (FFA), and very-low-density lipoprotein (VLDL) uptake, and decreased oxidation of FFA and export of triglycerides induced by inflammation and oxidative stress. Dysregulation of fat metabolism is usually always accompanied by excessive production of VLDL. This change is related to the induction of inflammation and oxidative stress. ${ }^{14}$

Based on the case-control study of Ratnasari et al (2012), there is a relationship between low HDL levels in patients with NAFLD. A low level of HDL can double the risk of NAFLD compared to individuals with normal HDL levels. ${ }^{15}$

Based on available data shows that 23 patients (67.65\%) had a BMI above normal, and $3(8.82 \%)$ 
patients with BMI below normal. The incidence of NAFLD is mostly found in obese individuals. In Asia, the incidence of NAFLD happens due to obesityrelated lifestyle changes. In the era of technological advances and improved living standards, people tended to follow a sedentary lifestyle and consumed a western diet that contains a high fat and sugar level., ${ }^{2,7}$

Based on Riset Kesehatan Dasar (Riskesdas) 2018 Indonesia, the incidence of obesity increased from year to year. Nationally, overweight and obesity occur in $35.4 \%$ for an individual $\geq 18$ years old. This percentage higher by $34.6 \%$ from 2013. Meanwhile, central obesity for people above 15 years old increased by $64.9 \%$ from 2007 to $2018 .{ }^{16}$ In the 21 st century AD, the problem of obesity continues to increase. ${ }^{1}$

However, NAFLD can also occur in $8-19 \%$ of individuals with underweight BMI. That condition happened due to the influence of the PNPLA3 gene. It is commonly found in Asian. This kind of NAFLD known as lean NAFLD ${ }^{6,7}$

From a blood sugar examination, $31.34 \%$ of patients suffer from hyperglycemia. Hepatocyte damage due to insulin resistance arises as a result of damage to the oxidation process of free fatty acids and fat peroxidation. This causes a buildup of reactive oxygen species (ROS) that can induce mitochondrial damage which results in the activation of stellate cells and kupffer cells so that inflammation occurs in hepatocytes. ${ }^{17}$

Based on the available data found, $44 \%$ had hypertension. NAFLD is a pathological change that occurs in the liver associated with risk factors for cardiovascular disease and metabolic syndrome. As part of the component of metabolic syndrome, hypertension is also often found in patients with NAFLD.$^{18}$ Increased activation of the renin-angiotensin-aldosterone system in hypertension can induce insulin resistance, it plays a role in the development of NAFLD. ${ }^{19}$

Based on a cohort study conducted by Aneni et al (2015), hypertension is associated with the development of NAFLD. The incidence of NAFLD increased from $5 \%$ in individuals with systolic blood pressure $<100 \mathrm{mmHg}$ to $70 \%$ in individuals with systolic blood pressure $>140 \mathrm{mmHg}$. Similar to systolic blood pressure, the increase of diastolic blood pressure also increases the prevalence of NAFLD. It increases from $6 \%$ in individuals with diastolic blood pressure $<70 \mathrm{mmHg}$ to $70 \%$ in individuals with diastolic blood pressure $\geq 90 \mathrm{mmHg}^{20}$

Patients with NAFLD usually asymptomatic, but sometimes patients feel mild symptoms. ${ }^{21}$ Nevertheless, the results of liver function tests on NAFLD often show an elevated level of enzyme alanine transaminase (ALT) and aspartate aminotransferase (AST). This enzyme examination is one of the tests that used widely and available in various health services and does not require high costs. Those test commonly used to be a screening test for NAFLD. ${ }^{22}$

In this study, $51.94 \%$ of patients experienced an increase in AST levels, and $49.36 \%$ of patients had ALT levels above normal. These results in accordance with research conducted by Martin et al (2017), which explains the increase in the ALT or SGPT and AST or SGOT. As a result of the accumulation of fat, there will be an increase in oxidation that supports inflammation in hepatocytes. If there are hepatocytes damage, the levels of ALT and AST will increase in the blood. ${ }^{1}$

Steatosis in the liver can be identified noninvasively through imaging, such as ultrasonography (USG), Fibroscan, computed tomography (CT), and magnetic resonance imaging (MRI). ${ }^{1}$ Evaluation of hepatic steatosis using ultrasound can be assessed based on changes in echogenicity in the liver parenchymal, and it is caused by the accumulation of intracellular fat vacuole which is reflected through the ultrasound so that a bright liver picture appeared as the result of increased the echogenicity of the liver parenchymal. ${ }^{23}$

Another diagnostic modality used to diagnose NAFLD is transient elastography (fibroscan). Fibroscan is a special ultrasound tool that can be used to assess liver stiffness due to fibrosis. In NAFLD, fibroscan can be an alternative diagnostic modality other than biopsy to assess staging of NAFLD especially to distinguish patients who experienced simple steatosis and steatohepatitis, although not perfectly. ${ }^{24}$

Computerized tomography scan (CT Scan) detect fatty liver due to the decrease of attenuation in the liver parenchyma. ${ }^{23}$ Magnetic resonance imaging (MRI) can detect fat in the liver in a small percentage, although only $1 \%$ fat is found. However, MRI cannot be used broadly, because of the higher cost and the radiation provided by this examination as well as its limited availability. ${ }^{25}$

The gold standard for the diagnosis of NAFLD is a liver biopsy. A liver biopsy can distinguish simple steatosis from NASH. ${ }^{23}$ Liver biopsy for examination in the diagnosis of NAFLD provides an overview of the stage and progression of the disease. ${ }^{1}$ Liver biopsy is an invasive modality to diagnose NAFLD. However, it is not commonly done for the first evaluation. ${ }^{23}$

In children, it is necessary to rule out metabolic disorders such as hemochromatosis and lysosomes- 
related disease to establishing the diagnosis of NAFLD. In children, there are a few possibilities of histological abnormalities, even with normal ALT levels or a slight increase. From the histopathological view, there are different structures of NAFLD in children and adults. In children, macrovesicular hepatocellular steatosis with portal inflammation and fibrosis is commonly found, and there is no hepatocyte balloon degeneration. ${ }^{1}$

The use of secondary data in this study led to several variables that were not fully written in the medical record. However, more data also needed to get an illustration perfectly of NAFLD patients in M. Djamil General Hospital.

\section{CONCLUSION}

The study found that the incidence of NAFLD was varied in different age ranges and sexes. Dyslipidemia was frequent. More than half of NAFLD patients have elevated AST and ALT levels. Abdomen ultrasound was commonly used as a diagnostic modality for recognizing fatty liver. Considering lean NAFLD in the Asian race, it will be perfect if there is a guideline to assist the management of NAFLD patients.

\section{REFERENCES}

1. Hassan K, Bhalla V, El Regal ME, A-Kader HH. Non-alcoholic fatty liver disease: a comprehensive review of a growing epidemic. World J Hepatol 2014;20:12082-101.

2. Liu A, Galoosian A, Kawala D, Li AA, Gadiparthi C, Cholankeril G, et al. Nonalcoholic fatty liver disease: epidemiology, liver transplantation trends and outcomes, and risk of recurrent disease in the graft. J Clin Transl Hepatol 2018;6:420-4.

3. Becares N, C. Gage M, Voisin M, Gutierrez LM, Liang N, Louie $\mathrm{R}$, et al. Impaired LX $\alpha$ phosphorylation attenuates progression of fatty liver disease. Cell Reports 2019;26:984-95.

4. Ikura Y. Transitions of histopathologic criteria for diagnosis of nonalcoholic fatty liver disease during the last three decades. World J Hepatol 2014;6:894 - 900.

5. Younossi Z, Anstee QM, Marietti, Hardy T, Henry L, Eslam M, et al. Global burden of NAFLD and NASH: trends, predictions, risk factors, and prevention. Nat Rev Gastroenterol Hepatol 2017;15:11-20.

6. Jian-Gao F, Seung-Up K, Wai-Sun WV. New trends on obesity and NAFLD in Asia. World J Hepatol 2017;67:862-73.

7. Younossi ZM, Koenig AB, Abdelatif D, Yousef F, Henry L, Wymer M. Global epidemiology of nonalcoholic fatty liver disease - meta analytic assessment of prevalence, incidence, and outcomes. Hepatology 2016;64:73-84.

8. Lonardo A, Ballestri, Marchesini, Angulo P, Loria P. Nonalcoholic fatty liver disease: A precursor of the metabolic. Dig Liver Dis 2015;47:181-90.

9. Estes C, Razavi H, Loomba R, Younossi Z, Sanya AJ. Modeling the epidemic of nonalcoholic fatty liver disease demonstrates an exponential increase in burden of disease. Hepatology 2018;67:12-33.
10. Bertolotti M, Lonardo A, Mussi C, Baldelli E, Pellegrini E, Ballestri S, et al. Nonalcoholic fatty liver disease and aging: epidemiology to management. World J of Gastroenterol 2014;20:14185-204.

11. Sub Direktorat Klasifikasi dan Pembakuan Statistik Direktorat Metodologi Statistik. Klasifikasi Baku Jenis Pekerjaan Indonesia. Jakarta. Badan Pusat Statistik 2002.p.1-19

12. Stepanova M, Avila LD, Afendy M, Younossi I, Pham H, Cable R, Younossi ZM. Direct and indirect economic burden of chronic liver disease in the united states. Clin Gastroenterol Hepatol 2017;15:759-66.

13. Syafitri V, Arnelis, Efrida. Gambaran profil lipid pasien perlemakan hati non alkoholik. Jurnal Kesehatan Andalas 2015;4:274-7.

14. Katsiki N, Mikhailidis DP, Mantzoros CS. Non-alcoholic fatty liver disease and dyslipidemia: an update. Metabolism 2016;65:1109-23.

15. Ratnasari N, Senorita H, Adie RH, Bayupurnama P, Maduseno $\mathrm{S}$, Nurdjanah S. Non-alcoholic fatty liver disease related to metabolic syndrome: a case-control study. Indones $\mathrm{J}$ Gastroenterol, Hepatol Dig Endosc 2012;13:8-13.

16. Kementrian Kesehatan Republik Indonesia. Hasil utama Riskesdas 2018 [serial online]. KemKes. 2018 [cited 2019 August 5]. Available from: https://www.kemkes.go.id/ resources/download/info-terkini/hasil-riskesdas-2018.pdf

17. Perla FM, Prelati M, Lavorato M, Visicchio D, Anania C. The role of lipid and lipoprotein metabolism in non-alcoholic fatty liver disease. Children 2017;4:18.

18. Yao ZC, Chen ZG, Yang Q, Zheng ZQ. Non-alcoholic fatty liver disease is associated with increased risk of hypertension and prehypertension: a systematic review and meta-analysis. Int J Clin Exp Med 2017;10:6876-82.

19. Qian LY, Tu JF, Ding YH, Pang J, Che XD, Zou H, et al. Association of blood pressure level with nonalcoholic fatty liver disease in nonhypertensive population. Medicine 2016;95:29.

20. Aneni EC, Oni ET, Martin SS, Blaha MJ, Agatston AS, Feldman T, et al. Blood pressure is associated with the presence and severity of nonalcoholic fatty liver disease across the spectrum of cardiometabolic risk. J Hypertens 2015;33:1207-14.

21. Khoonsari M, Azar MMH, Ghavam R, Hatami K, Asobar M, Gholami A, et al. Clinical manifestations and diagnosis of nonalcoholic fatty liver disease. Iran J Pathol 2017;12:99-105.

22. Martin-Rodriguez JL, Cantero G, Cantero AAG, Arrebola J, Gonzalez-Calvin JL. Diagnostic accuracy of serum alanine aminotransferase as biomarker for nonalcoholic fatty liver disease and insulin resistance in using 3T MR spectroscopy. Medicine 2017;96:1-9.

23. Lee DH. Imaging evaluation of non - alcoholic fatty liver disease: focused on quantification. Clin Mol Hepatol 2017;23:290-301.

24. Hashemi AS, Alavian MS, Fesharaki GM. Assessment of transient elastography (fibroscan) for diagnosis of fibrosis in non-alcoholic fatty liver disease: a systematic review and meta-analysis. Caspian J Intern Med 2016;7:242-52.

25. Lonardo A, Nascimbeni F, Targher G, Bernardi M, Bonino F, Bugianesi E, et al. AISF position paper on non-alcoholic fatty liver disease: updates and future directions. Dig Liv Dis 2017;49:471-83. 